\title{
Jarosław Płuciennik
}

\section{Dialogowość, literatura i wolność słowa*}

ABSTRACT. Płuciennik Jarosław, Dialogowośc, literatura $i$ wolnosć słowa [Dialogics, literature and liberty of speech]. „Przestrzenie Teorii" 9. Poznań 2008, Adam Mickiewicz University Press, pp. 69-82. ISBN 978-83-232-1917-0. ISSN 1644-6763.

A point of departure in my article is Francesco Loriggio's brilliant analysis Mind as Dialogue: The Bakhtin Circle and Pragmatist Psychology. My essay stands as a polemics with one of the main theses of Loriggio that dialogics should be divided into just two kinds: novelistic and theatrical one. I propose a more historical approach to the development of dialogics. In different cultural areas various practices and theories may form themselves in divergent ways. Since $17^{\text {th }}$ century, the development of the dialogics traveled from an apocalyptic - and demonizing its opponents discourse (John Milton's approach in Areopagitica), through dialogics of cooperation of obligations and laws (Polish Socinians, especially Jan Crell), dialogics of deduction (transcendental cooperation in I. Kant), through the dynamic dialogics of induction and creativity (John. S. Mill) to the dynamic fuzzy and multi-valued dialogics of a concept of rationality in R. Rorty or the theory of (un)free speech in S. Fish. Dialogics is not represented merely by two discoursive practices. I postulate existence of at least one medium discourse: deliberative rhetoric.

\section{Umysł jako dialog}

Punktem wyjścia mojego artykułu stała się świetna analiza z lat 90-tych XX wieku Francesco Loriggii pt. Umyst jako dialog: krag Bachtina $i$ psychologia pragmatyzmu ${ }^{1}$. Znajdujemy tam bardzo inspirujące porównanie między pojęciami wywodzącymi się z kręgu Bachtina a pragmatystycznym pojęciem umysłu. Pod koniec tego porównania jego autor sugeruje kilka bardzo ważnych dla zainteresowanych dialogowością wniosków:

Porównanie między kręgiem Bachtina a pragmatystycznym pojęciem umysłu pozostawia nam zatem kilka latwych do sformułowania sądów. Przyjmując jed-

- Artykuł jest oparty na referacie przedstawionym w trakcie Interdyscyplinarnej Konferencji Naukowej Dramatyczność $i$ dialogowość $w$ kulturze, zorganizowanej przez Pracownię Estetyki Literackiej Uniwersytetu im. Adama Mickiewicza i Zakład Teorii Literatury i Poetyki Uniwersytetu Warszawskiego, Kołobrzeg 16-19 października 2007. Wszystkim dyskutantom serdecznie dziękuję za uwagi, zwłaszcza Annie Krajewskiej, Barbarze Stelmaszczyk i Danucie Ulickiej. Dziękuję też za komentarze uczestnikom mojego seminarium, zwlaszcza Magdalenie Drabikowskiej i Patrycji Kruczkowskiej.

1 Ta analiza ukaże się w moim tłumaczeniu w Bachtin. Ja-Inny, pod red. D. Ulickiej, Kraków. Oryginał to Mind as Dialogue: The Bakhtin Circle and Pragmatist Psychology, „Critical Studies” 2: 1/2 (1990). 
ną opcję, wykorzystywaną z dużą pewnością siebie przez Łotmana, dialogika, w każdej swojej wersji jest przejawem szerszych procesów semiotycznych (symetria/asymetria). W innej opcji, dialogika dzieli się na różne gatunki: jest albo powieściowa, albo teatralna, jest dialogiem głosów bądź dialogiem gestów. Każda $\mathrm{z}$ tych opcji kusi wartościowe i bez wątpienia wybiórcze konteksty. Ale ta druga opcja daje świadectwo ważności i źródłowego bogactwa literatury i badań literackich, oraz ich wkładowi do myśli tego stulecia. Jako taka, uaktywnia ona różne składniki projektów bachtinowskich bądź pragmatystycznych, które tutaj w większości pozostawały nierozstrzygnięte. Czy oba gatunki są w rzeczywistości nieprzystawalne, i jak teksty literackie i literatura w szczególności docierają do umysłu i społeczeństwa oraz, nade wszystko, jaką drogą trafiają one do opisów umysłu i społeczeństwa, to jest dziedzictwo dla przyszłości, z którym będziemy się borykać jeszcze przez lata ${ }^{2}$.

Nie ma chyba wątpliwości, że dialogowość nazywana przez Loriggio dialogiką może być realizowana przez różne gatunki: jest ona albo powieściowa, albo teatralna, jest dialogiem głosów bądź dialogiem gestów, ale czy oba gatunki są w rzeczywistości nieprzystawalne, a zwłaszcza, czy tych gatunków jest tak mało? Czy nie powinniśmy widzieć $\mathrm{w}$ tych zjawiskach punktów skrajnych pewnego continuum? Chciałbym zastanowić się nad wspomnianą dychotomią i zanegować jej ostrość. Dialogika powieściowa, jeśli spojrzymy na nią z punktu widzenia pragmatystycznego, tak jak przedstawia rzecz Loriggio, może jawić się nam jako „pusty" dialog głosów, na takiej samej zasadzie, na której negowano całą literaturę, teatr i inne twory wyobraźni na gruncie pragmatystycznej przecież teorii aktów mowy wywodzącej się od Johna Austina.

Chciałbym zatem przyjrzeć się tej opozycji bliżej i zastanowić się nad dwoma obszarami refleksji antropologicznej i humanistycznej, jakimi są pragmatyzm i bachtinologia, zwłaszcza $w$ aspekcie ich relacji z filozofią umysłu i filozofią społeczną, bo na ich przykładach widać wyraźnie, że te dwa obszary refleksji muszą się splatać ${ }^{3}$. Technicznie rzecz biorąc, aby osiągnąć ów cel, postawiłem sobie zadanie skonfrontowania różnego typu koncepcji dialogiczności i wolności słowa - jest to przedsięwzięcie $z$ historii idei związanych $\mathrm{z}$ dyskusją nad wolnością słowa i tolerancją, od XVII wieku, kiedy dyskurs wolnościowy dawał już o sobie znać w sposób znaczący i zauważalny, aż po wiek XX, kiedy powróciła owa kwestia wolności słowa $\mathrm{w}$ zupełnie innych konfiguracjach kulturowych $\mathrm{z}$ innymi

2 Zob. także F. Loriggio, Anthropology, Literary Theory, and the Traditions of Modernism, w: Modernist Anthropology: From Field Work to Text, ed. by M. Manganaro, Princeton 1990.

3 O pragmatyzmie jako humanizmie pisze bardzo pouczająco, powołując się głównie na Williama Jamesa, M.P. Markowski w Antropologia, humanizm, interpretacja, w: Kulturowa teoria literatury. Glówne pojęcia $i$ problemy, pod red. M.P. Markowskiego i R. Nycza, Kraków 2006. Bachtin w oczywisty sposób jest bardzo nowoczesnym, pokantowskim humanistą. 
przestrzeniami i mediami wolności. Omawiam tutaj prace reprezentatywne dla poszczególnych okresów kultury. Czytelnik po tak krótkim tekście, jak ten, nie może spodziewać się niczego więcej aniżeli powierzchownego szkicu zarysowującego główne linie rozwojowe. Chciałbym przy tym argumentować za olbrzymim wkładem Polski w dyskurs nad wolnością słowa i tolerancją w wieku XVII ${ }^{4}$. Przypomnę kilka zapomnianych traktatów, które ujawniają swoją fundamentalną wartość, kiedy skonfrontować je $z$ światowymi głosami na tematy wolnościowe. Kontynuuję w tej pracy swoją myśl, że nowoczesność w Polsce to projekt szczególnie niedokończony. Podejmuję zatem uniwersalizujące tezy Jürgena Habermasa ${ }^{5}$.

\section{Areopagitica Johna Miltona i dialogika apokaliptyczno-rynkowa (1644)}

Najlepszym punktem wyjścia mojej analizy jest Areopagitica Johna Miltona z 1644 roku, która nie tylko dotyczy wolności i wolności słowa, ale jest najsławniejszym i najtrwalszym dziełem prozatorskim $\mathrm{w}$ dorobku Miltona, który wsławił się w świecie jednak nade wszystko swoją poezją ${ }^{6}$. Tekst wydrukowany został 23 listopada 1644 roku, bez licencji, bez

${ }_{4}$ Chciałbym przypomnieć tu klasyczne prace J. Tazbira, Dzieje polskiej tolerancji, Warszawa 1973; tegó், Reformacja - kontrreformacja - tolerancja, Wrocław 1996; tego ż, Państwo bez stosów. Szkice z dziejów tolerancji w Polsce XVI i XVII wieku, Warszawa 1967. Ostatnio problematyce tej poświęciliśmy dużo uwagi organizując w Uniwersytecie Łódzkim Interdyscyplinarną Konferencję pt. Literatura, kultura, tolerancja, 28-31 maja 2007 r. Konferencja trwała 4 dni, w czasie których odbywały się obrady plenarne w języku angielskim - oraz obrady w 4 sesjach równoległych, wyodrębnianych tematycznie i językowo (29-31 maja). Podczas obrad plenarnych wygłosiło wykłady 7 gości specjalnych. W sesjach zaprezentowano zaś 90 dwudziestominutowych referatów. Organizatorami tych wydarzeń były: Katedra Teorii Literatury Instytutu Teorii Literatury, Teatru i Sztuk Audiowizualnych Uniwersytetu Łódzkiego, British Council, Towarzystwo Naukowe Warszawskie, oraz stowarzyszenie społeczne Instytut Tolerancji w Łodzi. Patro-nat honorowy nad konferencją zgodzili się objąć członkowie Instytutu Tolerancji w Lodzi: legendarny przywódca powstania w Getcie warszawskim oraz honorowy obywatel Miasta Łodzi, Marek Edelman, jeden z najwybitniejszych polskich filozofów i Honorowy Prezes Instytutu, Leszek Kołakowski oraz Prezes Instytutu Tolerancji, Joanna Podolska.

5 J. Habermas, Modernizm - niedokończony projekt, przeł. M. Łukasiewicz, w: Postmodernizm. Antologia przekladów, pod red. R. Nycza, Kraków 1996. Oryginał pochodzi z 1980 r. Inspiruje mnie tutaj także szerokie pojmowanie nowoczesności preferowane także przez R. Nycza, O nowoczesności jako doświadczeniu, „Teksty Drugie” 2006:3. Rozwijam tę myśl w artykule J. Płuciennik, Nowożytne doświadczenie literatury. Od Psalterza Dawidowego Jana Kochanowskiego do... strumienia świadomości (w druku).

${ }^{6}$ Nie sposób wymienić wszystkie opracowania miltonologiczne i poświęcone wolności slowa, które wpłynęły na moją percepcję tego zagadnienia. Wymieniam tylko te najwięk- 
rejestracji, bez identyfikacji wydawcy i drukarza, i był to pierwszy angielski tekst $w$ całości poświęcony wolności słowa i druku. Bardzo znaczący jest fakt wzięcia odpowiedzialności za "wolne słowo" autora, który pozwolił się zidentyfikować na stronie tytułowej.

Ciekawie wygląda w tym traktacie (formalnie pismo jest określone jako mowa, ale nigdy jej nie wygłoszono przed parlamentem, wbrew informacji widniejącej na stronie tytułowej) związek filozofii umysłu i filozofii społecznej. Książki wedle Miltona są materialnym zapisem rozumowania i dysputy. One nie tylko zapisują wszystkie opinie i argumentacje, ale obejmują także prawdę w formie właściwego argumentu i udowodnionych faktów w zapisie, który mogą widzieć ludzie. Zatem: „ten kto zabija człowieka, zabija stworzenie rozumne, obraz Boży; ale ten kto niszczy dobrą książkę, zabija sam rozum, niszczy obraz Boży, tak jak on się jawi w żywym oku”. W kontekście dyskusji nad dialogowością nie można chyba przecenić tak śmiałego i tak nowoczesnego ujęcia tego zagadnienia. Presuponowana wizja „umysłu książek” wedle Miltona jest wizją rozumu publicznego, który jest umysłem rozumującym, debatującym i przez to samo dyskursywnym. Zabicie pojedynczego umysłu (albo okaleczenie ciała - materialnego jego nośnika) nie jest tak złowrogie i brzemienne w skutkach, jak cenzura książek, bo książki są przestrze-

sze i najbardziej podstawowe. Korzystam z elektronicznego wydania J. Milton, Areopagitica; A Speech of John Milton; For the Liberty of Vnlicenc'd Printing, Cambridge, Chadwyck-Healey 1999 (kopia pierwodruku z 1644, który znam także z autopsji) oraz z Areopagitica and Other Political Writings of John Milton, foreword by John Alvis, Indianapolis 1999. Ostatnio wyszła fundamentalna praca Milton \& Toleration, ed. by S. Achinstein and E. Sauer, Oxford, New York 2007, skupiająca prace na temat tolerancji u Miltona. Tu relewantne sa prace o prozie autorstwa Nigela Smitha, Dawida Loewensteina, Thomasa N. Cornsa, Nicholasa von Maltzahn, Jamesa Granthama Turnera, Jasona P. Rosenblatta, Victorii Silver, Martina Dzelzainisa, Andrew Hadfielda. Redaktorka wyboru jest autorką klasycznych opracowan. S. Achinstein, Milton and the Revolutionary Reader, Princeton, NJ 1994, czy tejże, Literature and Dissent in Milton's England, Cambridge 2003. Fundamentalne są także prace $w$ tej dziedzinie Stanleya Fisha, Driving from the Letter: Truth and Indeterminacy in Milton's Areopagitica, w: tegoz, How Milton Works, Cambridge, MA and London 2001; tegoż, There's No Such Thing Thing as Free Speech, and It's Good Thing, Too, w: tegoz, There's No Such Thing Thing as Free Speech, and It's Good Thing, Too, Oxford 1994. Bardziej ogólne prace znaleźć można w: B.K. Lewalski, The Life of John Milton, Oxford 2003 (prwd. 2000); The Cambridge Companion to Milton, $2^{\text {nd }}$ ed., ed. by D. Danielson, Cambridge 1999 (zwlaszcza hasła Martina Dzelzainisa i Thomasa N. Cornsa); A Companion to Milton, ed. by T.N. Corns, Oxford 2003 (prwd. 2001). Z książkowych opracowań zagadnienia wolności słowa pozostaję pod wplywem J.D. Peters, Courting the Abyss. Free Speech and the Liberal Tradition, Chicago and London 2005; L. Gearon, Freedom of Expression and Human Rights. Historical, Literary and Political Contexts, Brighton, Portland 2006. Popularna antologia publicystycznych wypowiedzi współczesnych na ten temat to Free Expression is No Offence, London 2005. 
nią ucieleśniającą rozum publiczny, mający w tej wersji sankcję boską. Nie jest żadnym anachronizmem dostrzeżenie u Miltona antycypacji Bachtinowskiej idei umysłu jako dialogu, jak również idei rozumu komunikacyjnego Habermasa?

Bardzo charakterystyczne, że Milton jest także radykalny w konkluzjach swojego traktatu, gdzie pisze: „Pozwólmy Prawdzie i Fałszowi zmagać się ze sobą". Stawia on wolne i otwarte doświadczenie ponad wszystkim. Znacząco daje o sobie znać protestancki indywidualizm i autonomia jednostki w konfrontacji z tradycją i doktryną, to żywy dialog wierzącego z Pismem może sprzyjać prawdzie. Ba, nawet samo Pismo jest wynikiem dialogu: „Nawet Mojżesz czy Paweł uczyli się od Egipcjan, od pogan, gdyby nie taka swobodna wymiana nie ukształtowana byłaby święta prawda pism". Zatem święta prawda pism, to nie monologowe kamienne inskrypcje, ale żywy dialog świętych z Bogiem i - o horrendum! - z poganami. Milton wyprowadził właściwe wnioski z Luterskiej determinacji $\mathrm{w}$ dyspucie $\mathrm{z}$ tradycją: dla obu Pismo jest najważniejszym punktem odniesienia, jednak dla Miltona samo Pismo święte jest także wynikłe z dysputy.

Poza tym warto od razu także zauważyć, że ów dialog różnych prawd jest $\mathrm{w}$ istocie dialogiem prawdy i fałszu, skąd wynika dramatyczność rozumiana jako egzystencjalne napięcie między wartościami. Jeśli bliżej przyjrzeć się Areopagiticom oraz innym pismom Miltona, konceptualizacja metaforyczna presuponowana przez jego dyskurs jest wyprofilowana niekonsekwentnie: $\mathrm{z}$ jednej strony sugeruje wolnościowy dyskurs rodzącego się rynku idei w przestrzeni publicznej, ta konceptualizacja jest dialogowo-demokratycznie-rynkowa. Z drugiej jednak strony, owo bardzo intensywne napięcie egzystencjalne między wartościami prawdy i fałszu nasuwa na myśl dyskurs z zupełnie innych rejestrów, bo apokaliptyczno-millenarystyczny. Tam właśnie zasadą jest ostre przeciwstawienie i ostra walka między dwoma pierwiastkami, dobrem i złem, czy, tak jak w Areopagiticach, walka prawdy i fałszu ${ }^{8}$. Tutaj można dostrzec swoistą dramatyczną dialektykę, która znajdzie swój odpowiednik w innych pismach Miltona w dialektyce logiki Ramusa. Niespójność tej konceptualizacji wynika $z$ zaangażowania religijnego Miltona oraz kontekstu historycznego: podczas rewolucji Cromwellowskiej w Anglii dyskurs apo-

7 Piszą o tym K. Pask, The Bourgeois Public Sphere and the Concept of Literature, "Criticism: a Quarterly for Literature and the Arts" 46:2 (Spring 2004) oraz D.L. Guss, Enlightenment as Process: Milton and Habermas, „PMLA” 106:5 (Oct., 1991).

8 Por. J. Płuciennik, Apokalipsa, w: Slownik rodzajów i gatunków literackich, pod red. G. Gazdy i S. Tyneckiej-Makowskiej, Kraków 2006, jak również tenże, Wyobraźnia apokaliptyczna $i 11$ września 2001" jako wydarzenie medialne i literackie, w: Apokalipsa. Symbolika, tradycja, egzegeza, t. 1, pod red. K. Korotkich i J. Ławskiego, Białystok 2006. 
kaliptyczny był całkiem naturalny9 ${ }^{9}$ Ów dyskurs jest prawdopodobnie odpowiedzialny także za bardzo ostre wykluczenie katolików z obszaru tolerancji: apokaliptyczna bestia w postaci papiestwa nie może być tolerowana, jeśli stoi za nią nie tylko świecka władza o zasięgu wszechświatowym, ale także Szatan jako ucieleśnienie zła. Taka rekonstrukcja sposobu myślenia Miltona jest zgadywaniem na podstawie kontekstu jego wystąpienia. Apokaliptyczna konceptualizacja nie jest profilowaniem światopoglądowym możliwym do pogodzenia z perspektywą rynkowych negocjacji, gdzie popularną dyskursywną strategią jest negocjacyjna plastyczność: w polskim języku świetną metaforą, a właściwie metonimią, jest słowo „targować się". Targowania się nie można pogodzić z dyskursem apokaliptycznego zniszczenia, rozsądek targowania nie daje się uspójnić z ambiwalentnym uniesieniem wzniosłości profetyzmu. Logika apokaliptyczna to dialogika w sensie dosłownym, bo jest to logika dwóch przeciwstawnych wartości i światów. W tym sensie dialogika apokaliptyczna przypomina dialektykę przeciwstawień Ramusa, którego zwolennikiem i tłumaczem, a także propagatorem był Milton. Zaskakujące może być to, że ślady takiej dialogiki dwóch głównych wartości odnaleźć można także u Bachtina w jego koncepcji karnawalizacji ${ }^{10}$. Wojna postu z karnawałem bazuje na logice przeciwstawień i jest logiką apokaliptyczną, co najlepiej widać w sztukach plastycznych i literaturze, w których ten motyw zaznacza się jakością estetyczną groteski. Podobną zresztą logikę, wojny karnawału z postem, znajdziemy u autora znacznie wcześniejszego od Bachtina, u lorda Shaftesbury: entuzjazm profetyczny przeciwstawia się testowi obśmiania, satyry ${ }^{11}$. Streszcza się ten wątek najlepiej w metaforze „Bartłomiejowego jarmarku” będącej konceptualizacją rynkowej i demokratycznej satyry na profetyczno-apokaliptyczne uniesienia, zwłaszcza jeśli pamiętać o możliwych relacjach tej metafory Shaftesbury'ego do dramatu Johnsona, satyrycznie przedstawiającego prawe i sprawiedliwe uniesienia purytanów. „Bartłomiejowy jarmark” to ucieleśnienie teatru i literatury, żywiołów już co prawda demokratycznych, ale jednak jeszcze zakorzenionych $\mathrm{w}$ przednowoczesnym świecie walk apokaliptycznych sił.

${ }^{9}$ Ch. Hill, The World Turned Upside Down. Radical Ideas During the English Revolution, London 1972.

10 M. Bachtin, Twórczość Franciszka Rabelais'go a kultura ludowa średniowiecza i renesansu, przeł. A. i A. Goreniowie; oprac., wstęp, komentarze S. Balbus, Kraków 1975. Por. W. Bolecki, Język. Polifonia. Karnawal, w: tegoż, Polowanie na postmodernistów (w Polsce), Kraków 1999; A. Szah aj, Ponowoczesność - czas karnawalu. Postmodernizm - filozofia blazna?, w: Postmodernizm a filozofia, pod red. S. Czerniaka i A. Szahaja, Warszawa 1996.

11 Piszę o tym w J. Pluciennik, Nowożytny indywidualizm a literatura. Wokót hipotez o kreacyjności Edwarda Younga, Kraków 2006. 


\section{O wolność sumienia Jana Crella (1637) - dialogika rynkowa i oświecenie w wieku XVII}

Inaczej wygląda sytuacja u bardziej w Polsce znanych socynian, czyli Braci Polskich ${ }^{12}$. W ich wystąpieniach skupionych wokół kwestii tolerancji i wolności sumienia przywoływane są różne niekonfrontacyjne regulatory dyskursu publicznego, które być może nie postulują absolutnej wolności słowa (nie wiadomo, czym miałoby to być), ale proponują regulacje całkiem różne od rozwiązań $\mathrm{z}$ jednej strony siłowych (prześladowanie i cenzura), z drugiej zaś od negacji apokaliptyczno-satyrycznej. Pojawia się u nich konceptualizacja całkowicie poddana dyskursowi rynkowemu, "targującemu się", negocjacyjnemu. Najlepiej widoczne się to staje w traktacie $O$ wolności sumienia Jana Crella, który był sławny w Europie i wydawany aż czterokrotnie w samym XVII wieku (w 1637, 1650, 1666 , i w 1681)13. Miał prawdopodobnie duży wpływ na powstanie niezwykle oświeceniowych Listów o tolerancji Johna Locke'a. W traktacie Crella znaleźć można antycypacje rozwiązań właściwie Kantowskich i oświeceniowych, bo Crell przywołuje fragmenty Pisma Świętego, wskazujące na zasadę wzajemności: "nie czyń drugiemu, co Tobie niemiło" (rzecz prawdopodobnie pochodzi z niezaakceptowanej przez protestantów jako kanoniczna Księgi Tobiasza (4, 66).), czy też „Co chcielibyście, aby wam ludzie czynili, to wy czyńcie innym”. (Mat. 7.12) Te argumenty mają uzasadnić zasadę kooperacji strony katolickiej i protestanckiej: jeśli katolicy przysięgali nieprześladowanie, to nie mogą tej przysięgi po prostu przekreślać, bo obiecywali. W tym miejscu widać konceptualizację w pełni rynkową: mamy tu zaprojektowany dialog szczerości i wierności, polubownego zobowiązania i obietnicy, dyskursów opartych na komunikacyjnej zasadzie kooperacji i wzajemności. Nota bene, późniejsza o trzy wieki koncepcja Paula Grice'a zasady kooperacji wywodzi się z pełnorynkowej koncepcji dyskursu Johna Austina. Ten dialog przysięgi jest jednocześnie dialogiem obligacji obrzędu. Swoista obrzędowość stwarza zobowiązania i sieci oraz układy oparte na zaufaniu. Dyskurs targowania się, który nie polega na ślepej wierze, a wybiera równouprawnione negocjacje przynajmniej dwóch stron, jest dyskursem nie tylko antyapokaliptycznym, ale także posiada moc kreacji więzi społecznych, żeby nie powiedzieć społeczeństwa w ogóle.

12 Zob. Myśl ariańska w Polsce. Antologia tekstów, wybór oprac. i wstęp Z. Ogonowski, Wrocław 1991; Literatura ariańska $w$ Polsce XVI wieku, oprac., wstęp i przyp. L. Szczucki i J. Tazbir, Warszawa 1959; J. Tazbir, Bracia polscy na wygnaniu. Studia z dziejów emigracji ariańskiej, Warszawa 1977.

13 J. Crell, O wolność sumienia, przeł. I. Lichońska, wstęp i przyp. Z. Ogonowski, Warszawa 1957. 
Moja interpretacja tego pisma Crella wskazuje jednoznacznie na to, że oświeceniowe koncepcje rozumu publicznego rodziły się już w XVII wieku, a nie dopiero w wieku XVIII, kiedy pod jego koniec ma miejsce w Niemczech słynna dyskusja nad tym, co to jest oświecenie? ${ }^{14}$.

\section{Co to jest oświecenie? (1790) Kant a bracia polscy. Dialogika dedukcji transcendentalnej}

Swietnie to widać na przykładzie koncepcji dialogu oświeconego rozumu u Andrzeja Wiszowatego ( $O$ religii zgodnej $z$ rozumem 1676$)^{15}$, który wyprzedza o całe stulecie rozwiązania zaproponowane i wysubtelnione przez Kanta (Krytyka wladzy sadzenia 1790). Pośrednikiem mogłaby być prawdopodobnie logika Leibniza ${ }^{16}$. U Wiszowatego właśnie rozum znajdziemy jako ideę regulatywną wolnej debaty (wprost występuje u niego intelligibilność, wykluczony jest bełkot i niezrozumiałość natchnionego prorokowania, co znajduje do pewnego stopnia potwierdzenie w Piśmie). W koncepcji Kanta natomiast występuje praktyczny rozum (sensus communis aestheticus), który wyklucza egotyzm kartezjański17.

U Kanta z jednej strony znajdziemy sugestię nieograniczonej wolności, także debaty, przynajmniej w ramach akademii, co wydaje się dzisiaj minimalizmem. W artykule Co to jest oświecenie? (1784) pada często przywoływana definicja oświecenia:

Oświeceniem nazywamy wyjście człowieka z niepełnoletności, w którą popadł $\mathrm{z}$ własnej winy. Niepełnoletność to niezdolność człowieka do posługiwania się swym własnym rozumem, bez obcego kierownictwa. Zawinioną jest ta niepełnoletność wtedy, kiedy przyczyną jej jest nie brak rozumu, lecz decyzji i odwagi posługiwania się nim bez obcego kierownictwa ${ }^{18}$.

14 Piszę o tym w J. Pluciennik, Oświecenie i niekończqca się opowieść literatury, w książce zbiorowej Awangardowa encyklopedia (w druku).

${ }^{15} \mathrm{~A}$. Wis z ow aty, $O$ religii zgodnej $z$ rozumem, czyli traktat o postugiwaniu się sqdem rozumu także $w$ sprawach teologicznych i religijnych, przeł. E. Jędrkiewicz, wstęp i przyp. Z. Ogonowski, Warszawa 1960.

${ }^{16}$ Zob. S. Huber, Logika i wiara w sporze Andrzeja Wiszowatego i Gottfrieda Wilhelma Leibniza o Trójcę Św., Warszawa 2005; Z. Ogonowski, Leibniz i socynianizm, „Odrodzenie i Reformacja w Polsce” XXVI, 1981.

17 Z koncepcją nowoczesności kojarzy Kanta także A.J. Cascardi, Consequences of Enligthenment, Cambridge, New York, Melbourne, 1999, s. 48 i ostatni rozdział. Książka ta jest suplementem do wcześniejszej rozprawy Cascardiego, The Subject of Modernity, Cambridge, New York, Melbourne 1992.

18 I. Kant, Co to jest Oświecenie?, w: T. Kroński, Kant, Warszawa 1966. 
Można powiedzieć, że zaufanie we wzajemnym relacjach $\mathrm{w}$ ramach demokratycznych dyskursów targujących się, negocjacyjnych musi także postulować zaufanie do samego siebie, a to będzie nie do osiągnięcia bez autonomii jednostki. Rynek wymusza równouprawnienie, które emancypuje jednostki uczestniczące w negocjacjach.

Nieco rzadziej przywoływanym tekstem Kanta definiującym oświecenie (częściej przywołuje się Co to jest oświecenie?) jest rozdział 40 Analityki wzniostości w jego Krytyce władzy sq̨dzenia. Tam właśnie oświeceniem nazywane jest uwolnieniem od przesądów, a zwłaszcza od zabobonu ${ }^{19}$. Zabobon sprowadza ślepotę i - co więcej - wymaga jej, a jest rozumiany jako świadectwo istnienia potrzeby podlegania kierownictwu ze strony innych. Zabobon zakłada brak autonomii jednostki. Z oświeceniem zatem, wedle Kanta, związane bylyby omawiane przez niego trzy maksymy pospolitego rozsądku ludzkiego, które można wykorzystać do charakterystyki zagadnień smaku. Nawiasem mówiąc, bardzo charakterystyczne, że u Shaftesbury'ego sensus communis był bardziej zmysłem dobra wspólnego czy też dobra obywatelskiego aniżeli pospolitym zmyslem. Maksymy Kanta to: 1) myśleć samemu; 2) myśleć, wstawiając się w miejsce każdego innego człowieka; 3 ) myśleć zawsze w zgodzie ze samym sobą. Warto podkreślić, że $z$ oświeceniem nie jest utożsamiana jedna tylko maksyma intelektu, którą wyraźnie widać w wątpiących medytacjach Kartezjańskich - tam była ona początkiem i celem autorytetu. Indywidualizm osamotnionego umysłu Kartezjusza nie jest celem Kanta. Kant dodaje dwie maksymy: smaku (osądu estetycznego) i rozumu. Maksyma smaku nakazuje poszerzyć (to pojęcie samego Kanta) własną podmiotowość poprzez „szerszy sposób myślenia”, który pozwala jednostce „wznieść się ponad subiektywne warunki indywidualne sądu”. Maksyma rozumu jest wynikiem praktykowania dwóch wcześniejszych: jeśli często myślimy samodzielnie i wstawiamy się w innego, to łatwiej nam być konsekwentnym względem wlasnych osądów. Wydaje mi się, iż metaforyka przestrzenna Kanta widoczna w takich konstrukcjach jak szerokość myśli, wzniesienie ponad jednostkę, proces poszerzenia myślenia, jest metaforyką wzniosłości par excellance. „Poszerzenie myśli” jako wyrażenie jest wynikiem dyskursu, w którym centrum konceptualnym jest ruch wznoszenia się ponad siebie i wychodzenia $\mathrm{z}$ siebie. Te wyrażenia wyrastają ze wspólnego konceptualnego pnia ex-stasis. Ale tutaj jedyne, co jeszcze przywodzi na myśl ten ruch entuzjazmu i ekstazy, to estetyka: jesteśmy na gruncie rozważań o smaku, który jest „władzą orzekania a priori o zdolności udzielania się uczuć połączonych (bez pośrednictwa pojęcia) z danym przedstawieniem”, czyli „sensus communis aestheticus”.

${ }^{19}$ I. Kant, Krytyka wladzy sq̨dzenia, przeł. J. Gałecki, Warszawa 2004, s. 211-212.

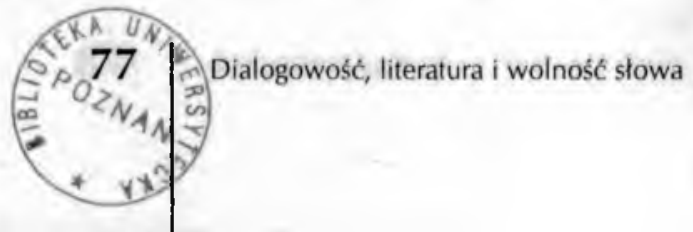


Można powiedzieć, że kategoryczność Kanta niweluje jego uznanie dla podmiotowości, bo uznaje i jednocześnie neguje: „uczucie zostaje w sądzie smaku imputowane każdemu poniekąd jako obowiązek"20. Dialogika Kanta jest dialogiką rozumu o transcendentalnych pretensjach.

Podsumowując można powiedzieć, że u Wiszowatego mamy klasyczną dialogikę dedukcji Arystotelesa, zaś u Kanta dialogikę transcendentalnej dedukcji, która jest dialogiką autonomii i intersubiektywnej ekstazy (wychodzenia z siebie i identyfikowania się z innymi). Są to „inni” modelowi - w tym tkwi totalitarny wymiar myśli Kanta, jednak to wyjście ku nim, wychylenie i otwarcie presuponują dialogowy a nie monologowy model umysłu. Sposób myślenia w tym modelu jest dyktowany dedukcją, istnieją tutaj abstrakcyjne zasady regulujące dialog.

\section{O wolności (1859) Johna Stuarta Milla - ewolucyjna dialogika indukcyjna}

Zupełnie różny model myślenia znajdujemy w następnym wielkim tekście - który jednocześnie ustanawiał wielki fakt wolnościowy - w traktacie $O$ wolności Johna Stuarta Milla (1859)21. Jeśli ujęcie Kanta streszczało jakoś wiek XVIII, to Mill świetnie syntetyzuje tendencje wieku XIX. U Milla znajdziemy nie tyle modelowego ,innego” i dialog dedukcji, co dialog autentycznej różnorodności podmiotów, który jest zarazem dialogiem kreacyjności. „Nie ma wolności bez różnorodności” i „nie ma twórczości bez różnorodności”. Społeczny dyskurs jest oświeconym, a zatem samoświadomym i wychylonym ku innemu, dialogiem różnorodności, ale mniejszość powinna być chroniona przed tyranią większości. Regulator w postaci postępowej kreacyjności albo inwencji sprawia, że nie można uciszyć prawd wydających się dzisiaj niesłuszne, bo nie wiadomo, jaka sytuacja będzie za lat kilka, kilkanaście, kilkadziesiąt... A jeśli nie wiadomo, jeśli uznajemy ewolucyjny sposób dochodzenia do prawdy, społeczeństwo może ponieść niepowetowaną szkodę, wykluczywszy jakieś inne punkty widzenia. Mill uznaje już ewolucję i użyteczność inwencji naukowych, stąd można powiedzieć, że wykracza poza oświeceniową dialogikę, pojawia się już tutaj dialogika indukcji prowadzącej do inwencji i kreacji. Dyskurs społeczny u Milla to dialogika indukcji ewolucjonistycznej. Najistotniejszym wynalazkiem Milla jest jednak to, że głównym i właściwie jedynym regulatorem dyskursu jest tzw. zasada „krzywdy

20 Tamże, s. 214.

21 J.S. Mill, O wolności, przeł. A. Kurlandzka, w: tegoż, Utylitaryzm. O Wolności, wstęp T. Kotarbiński, Warszawa 2005. 
innego”. Wolność posiada wędzidło w postaci zasady „krzywdy innego”: można mówić wszystko, co nie krzywdzi w mniej lub bardziej bezpośredni sposób innych.

\section{Pragmatystyczna dialogika powieściowa - racjonalność Fisha i Rorty'ego}

Dwudziestowieczne dylematy wokół relacji wolności słowa i literatury świetnie wydaje się podsumowywać Stanley Fish, który jest autorem słynnego manifestu pt. Nie ma takiej rzeczy jak wolne stowo. I to jest także dobra rzecz (1994)22. Według autora opowiadającego się za pragmatyzmem i retorycznością zawsze istnieją ograniczenia wolności słowa wynikające $\mathrm{z}$ ochrony żywotnych interesów jakichś grup lub jednostek, z lęku przed praktykami wykluczenia i nienawiści: nie istnieje wolność slowa, nawet w ramach akademii nie można o niej mówić, gdyż akademia jest przestrzenią publiczną ${ }^{23}$. Zatem jednostki posiadają indywidualne regulatory, które zawsze nakładają ograniczenia na dyskurs w przestrzeniach publicznych. Można zasadnie zastanawiać się, czy nie ma w wizji Fisha żadnego regulatora ponadindywidualnego. Wydaje się, że intersubiektywnym regulatorem dyskursu jest grzecznościowy i czasami prawny zakaz mowy nienawiści i eliminacji, przy czy rządzi nim charakterystyczna dla Ameryki Północnej filozofia pojedynczych przypadków i precedensów. Bardzo charakterystyczne jest to, że idea tego grzecznościowego regulatora jest kolejną wersją Millowskiej zasady „krzywdy innego". Inaczej mówiąc, regulatorem dyskursu jest zasada poprawności, wynikająca $\mathrm{z}$ wrażliwości na krzywdę ludzką. Jednak owa krzywda nie może być abstrakcyjnie sformułowana jako zasada: każdy przypadek należy rozpatrywać oddzielnie. Fish ostro występuje przeciwko idei absolutnej wolności słowa: często owa idea jest wykorzystywana przez dyskursy i postawy monologowe, nie tylko postulujące krzywdę innego, ale i mające zapędy totalizujące i niewątpliwie, jak ująłby to Bachtin, monologowe. Zatem, „nie ma tolerancji dla nietolerancji”. Dialog nie toleruje monologu, dialogika wyklucza absolutystyczną logikę formalną.

Podsumowaniem tej krótkiej historii dyskursu o wolności słowa chciałbym uczynić szkic o pragmatystycznej koncepcji racjonalności Ri-

22 Tamże.

23 Można też znaleźć owe tezy w bardziej popularnej formie w felietonach w „New York Timesie" Think Again, w listopadzie 2007 i styczniu 2008. 
charda Rorty'ego z 1992 r. ${ }^{24}$ Wyróżnia on w nim trzy typy racjonalności i trzy definicje kultury; 1) racjonalność tożsamą z instynktem samozachowawczym, inteligencją; 2) racjonalność jako godność typowo ludzką; 3) racjonalność jako tolerancję. Dwie pierwsze mają charakter raczej monologowy, jeśli przyjąć perspektywę Bachtina, trzecia natomiast jest dialogowa, przy czym dialogiczność byłaby rozumiana jako zdolność do wymiany perspektyw. Można nazwać ten typ dialogiczności dialogiem kubistycznym. Wydaje mi się, że ten szkic wyraźnie wskazuje właśnie na nowoczesną sztukę i nowoczesną literaturę jako siedlisko racjonalności, przy czym owa racjonalność jest swobodnym dialogiem różnorodności prawd nieostatecznych ${ }^{25}$.

\section{Wnioski. Dialogika deliberacyjna}

Chciałbym powrócić do punktu wyjścia moich rozważań, to jest do refleksji Loriggii i jego pytania, czy istnieje przeciwieństwo (w domyśle: pełnego) dialogu gestów i ( $w$ domyśle: pustego) dialogu głosów? Czy istnieją dwa typy dialogów wraz z towarzyszącymi im różnymi filozofiami umysłu, powieściowe i teatralne? Pomijam w tym miejscu niebagatelny problem wykluczenia np. dialogu liryki tkwiący u samego Bachtina. Pragnę postulować istnienie co najmniej jednego dyskursu pośredniczącego: między dialogiem performatywnym (teatralnym) a powieściowym dialogiem głosów istnieje np. retoryczna mowa deliberacyjna. Charakterystyczna dla mowy deliberacyjnej jest formuła ,jeśli... to"26. Myślę, iż owa formuła to prawdziwie godnościowy wyróżnik homo sapiens, wykraczająca poza apokaliptyczne myślenie czarno-białe, dwóch wartości logicznych - prawdy i fałszu. Warunkowy sposób mówienia, charakterystyczny dla implikacji logicznych jest historycznie i typologicznie wiązany z kreacją przestrzeni probabilistycznej, w której jest miejsce na

24 A Pragmatist View of Rationality and Cultural Difference, „Philosophy East \& West" 42:4 (October 1992). Zob. tamże, Racjonalność i różnica w kulturze: ujęcie pragmatyczne, przeł. L. Witkowski, „Kultura Współczesna” 1/1993.

${ }_{25}$ Zob. R. Rorty, Zmierzch prawdy ostatecznej, przel. A. Szahaj, „Teksty Drugie” 84 (2003: 6) oraz tenże, Wybawienie od egotyzmu, przel. A. Żychliński, „Teksty Drugie” 97/98 (2006: 1/2).

${ }^{26}$ Zob. D. Cohen, The Politics of Deliberation: Oratory and Democracy in Classical Athens oraz D.J. Smigelskis, Deliberation (and topics): Cultivating Deliberating: Mindfully Resourceful Innovation In and Through the Federalist Papers, w: A Companion to Rhetoric and Rhetorical Criticism, ed. by W. Jost and W. Olmsted, Oxford 2006 (prwdr. 2004). 
rozważania modalnościowe ${ }^{27}$. Właśnie $\mathrm{w}$ mowach deliberacyjnych miało miejsce opowiadanie wymyślonych historii „na próbę”, „tak jakby”, ,jeśli... to...”. To jest początek nowoczesnej literatury i perspektyw kubistycznej dialogiki. Oczywiście deliberowanie posiada różne odmiany: od prywatnych rozważan, przybierających często formę solilokwium, poprzez publiczny dyskurs pośredniczący w postaci debatowania, aż po swobodną, kawiarnianą rozmowę. Od czasów co najmniej twierdzeń Habermasa to właśnie kawiarnie stanowiły uznaną przestrzeń kultury, gdzie narodziła się przestrzeń publiczna będąca domeną rozumu komunikacyjnego ${ }^{28}$. Wszystkim tym deliberacyjnym dyskursom pośredniczącym można by przyporządkować różne przestrzenie, kawiarnia byłaby tylko jednym $\mathrm{z}$ ogniw architektonicznych. Innym ogniwem mógłby być mebel $\mathrm{w}$ postaci okrągłego stołu, jeszcze innym akademie florenckie w renesansie.

Deliberowanie mogło doprowadzić przy pomocy różnych antycypujących struktur dyskursywnych do powstania dialogiki kubistycznej. Nie jest przypadkiem że solilokwium wymienia się jednym tchem ze strumieniem świadomości. Dialogiczność kubistyczna, w tym także dialogiczność wybitnych powieści XX wieku, opiera się na dialogice nieostrych zbiorów, w której mamy do czynienia ze sposobem myślenia charakterystycznym dla konstrukcji warunkowych, czyli logiką rozmytą i wielowartościową.

$27 \mathrm{O}$ modalności w kontekście literaturoznawstwa pisal Włodzimierz Bolecki w Modalność - literaturoznawstwo i kognitywizm, „Teksty Drugie” 2001: 5. W Polsce na gruncie logiki propagatorem tego typu myślenia jest zarówno Witold Marciszewski, jak i Grzegorz Malinowski, Logiki wielowartościowe, Warszawa 2006. W tych logikach ujawniają się dwie tradycje: Łukasiewicza oraz Zadeha. Pierwszy o fuzzy sets zaczął pisać L.A. Zadeh, Fuzzy Sets, „Information and Control” 8 (1965). Przedruk w: Fuzzy Sets and Applications: Selected Papers, ed. by L.A. Zadeh, R.R. Yager et. al., New York 1987. Zob. także tegoż, Fuzzy logic and Approximate Reasoning, „Synthese” 30 (1975). Tradycja podobnego myślenia o semantyce jest długa i sięga nawet do Diogenesa Laertiosa, Galena i Cycerona. W nowszych czasach w 1923 roku o nieostrości nauczał także Bertrand Russell, a w 1937 Max Black, znany teoretyk także metafory, twórca tzw. teorii interakcyjnej. Eksplozja zainteresowania miała miejsce w latach siedemdziesiątych: wtedy pisali James Cargile, Kit Fine, Kenton Machina, Michael Dummett, Crispin Wright. Najnowsze wystą-pienia w tym względzie to artykuły Crispina Wrighta, R.M. Sainsbury'ego, Timothy'ego Williamsona, Michaela Tye'a, Dorothy Edgington, Garetha Evansa, Davida Lewisa Terence'a Parsonsa oraz Petera Woodruffa. Zob. R. Keefe i P. Smith, Introduction: Theories of Vagueness, w: Vagueness: A Reader, ed. by R. Keefe, P. Smith, Cambridge, Mass 1996. W tej koncepcji mogą spotkać się pokojowo bachtinolodzy, kognitywiści i pragmatyści oraz postmoderniści.

28 J. Habermas, Strukturalne przeobrażenia sfery publicznej, przel. W. Lipnik, M. Łukasiewicz, Warszawa 2007. 
Postuluję zatem ujęcie bardziej historyczne, które przedstawiłoby rozwój dialogiki, niekoniecznie tożsamy z etapami historycznymi - jest to raczej nawarstwianie się praktyk i teorii społecznych oraz ich rezultatów. W różnych obszarach kulturowych i geograficznych owe praktyki i teorie mogą różnie się formować. Od XVII wieku ów rozwój przeszedł długą drogę od dialogiki apokaliptycznej, demonizującej przeciwnika, i będącej odpowiednikiem dialogiki Ramusa; przez dialogikę obrzędu i prawa (kooperacji), dialogikę dedukcji (kooperacji transcendentalnej), dynamiczną dialogikę indukcji i kreacyjności aż po dynamiczną dialogikę zmąconą (kubistyczną), rozmytą, znajdującą w badaniach literackich i okołoliterackich świetnego reprezentanta w teorii racjonalności Rorty'ego. Dialogiczność nie jest reprezentowana tylko przez dwie struktury dyskursywne. Wymienione przeze mnie gatunki pośrednie wynikają z prywatnego i publicznego deliberowania, tak czy inaczej będącego sposobem osiągania samowiedzy i autonomii. Można przypuścić, iż rozwój, o którym piszę, nie jest rozwojem równomiernym i uniwersalnym. Istnieją kraje i kultury, gdzie nowoczesna literatura nie miała powodzenia, nie miała też powodzenia dialogika kubistyczna. Można wskazać choćby dzieje powieści np. w Turcji i w Polsce, zupełnie różne dzieje od jej historii w krajach liberalno-demokratycznych. Być może ma ten fakt związek $\mathrm{z}$ niedokończonym projektem oświecenia. Ale to już inna historia i inne deliberacje. 